\title{
SEARLES VALENTINE WOOD, F.G.S.
}

BorN Feb. 14th, 1798 ; Dred OCT. 26TH, 1880.

$\mathrm{M}$

R. WOOD was born on St. Valentine's Day, 1798, hence his name.

He went to sea as a midshipman in the "Thames" (one of the East India Company's mercantile fleet) in 1811; and continued in that service until the year 1826, when, being disappointed in obtaining the command of a ship that had been promised him, he retired from a maritime life, and devoted himself to palæontological studies. Settling in his native place in Suffolk, he gave the larger part of his attention to the Crag, but he collected extensively from the Hampshire Tertiaries; and for the purpose of working out the relation of these to the beds of the Paris basin, he formed an extensive collection of the French Eocene Mollusca.

From these materials, and from correspondence with Deshayes and other French savans, he was prepared to have taken up the description of the English Eocene Mollusca Iong before he actually did so, circumstances having determined his undertaking the description of the Mollusca from the Upper Tertiaries first. He also formed a considerable collection of recent Mollusca for comparison in working out the relations of the Mollusca from Tertiary formations. Having left Suffolk from ill-health, and settled in London, he was in 1837 introduced to Sir Charles (then Mr.) Lyell; and was associated with bim in the endearour in which Lyell was then mainly engaged, to work out a better knowledge of the Tertiary formations, which up to a period not long before that time had been regarded as of small account, in comparison with the "Secondary" group. In this task Lyell relied principally on $\mathrm{S}$. V. Wood and the late G. B. Sowerby for the determination of the identity of the Molluscan remains from various countries with those found fossil in England, and with the Molluscan fauna living in existing seas, as far as these were then known. Mr. Wood also for a few months about this time acted as Curator of the Museum of the Geological Society.

Urged to the task by Lyell, he commenced (with the co-operation of the present G. B. Sowerby as engraver and intended publisher), the description of the "Crag Mollusca"; and considerable progress having been made with the manuscript and plates of the first, or "Univalve" part of this work, when the Palæontographical Society was formed in 1847, this part formed the first volume of the magnificent series of scientific publications which have been issued by that Society. "The rest of the "Crag Mollusca" followed in subsequent years; and upon the completion of this work, and in recognition of his labours generally in connexion with the Tertiary Mollusca, the Council of the Geological Society awarded to Mr. Wood in the year 1860 the Wollaston medal. A large supplement to this work, embodying the discoveries which had subsequently accumulated, was prepared by Mr. Wood; and this, accompanied by an introduction describing geologically the formations from which the remains embraced by the work had been obtained, from the pen of his son and of Mr. F. W. Harmer, was issued by the Palæonto- 
graphical Society, in 1871 and 1S73. A second supplement followed this in 1879, and Mr. Wood was actively engaged up to the day of his seizure with fatal illness on another small addition. On the completion of the description of the Molluscan remains from the Crag, Mr. Wood presented the unrivalled collection of them, which he had been forming during thirty years, to the nation; in order that, by being preserved intact in the British Museum, the types of all the forms which had been described and figured by him in his work (save two or three which belonged to other persons), might be available for examination and comparison by naturalists engaged in similar labours.

He also presented to the nation the valuable collection of vertebrate remains (including among them the unique jaws of Alligator Hantoniensis, and Hicrocharus erinacens), which he bad in 1843-5 extracted from the Eocene Freshwater beds of Hordle Cliff; and from which beds up to the time when he commenced to form this collection no such remains had been known. These he partially figured and described in the London Geological Journal; but the stoppage of that priblication brought this part of his labours to an unexpected termination. In 1850 , having the advantage of an unrestricted manipulation of the more extensive collection of Eocene Mollusea which had been formed by his friend F. E. Edwards, he commenced the description of the Eocene Bivalvia, Mr. Edwards taking upon himself (and having commenced before this) the Cephalopoda and Gasteropoda; and several parts of this work were issued by the Palæontographical Society. Failure of health put a somewhat premature period to Mr. Edwards' share in this work, but $\mathbf{M r}$. Wood continued his share for some years longer, relinquishing it only when, shortly before Mr. Edwards' death, this collection was acquired by the British Museum. During the time in which it remained in Mr. Edwards' possession he was accustomed to place in Mr. Wood's care, for study at his leisure, all specimens he possessed which in any way illustrated the subject in hand, but this the transfer of the collection to the British Museum rendered impracticable; and as it was Mr. Wood's feeling that in addition to that opportunity for careful study, all forms as to which any doubt existed ought to be carried abroad and compared with those in the Museums of France and Belgium, if justice was to be done to the subject, and as at his advanced age he was unable to accomplish this, he on the issue of the part in the volume of the Palæontographical Society for 1877 relinquished the further prosecution of the " Eocene Bivalvia," though he subsequently added a small contribution (both to $\mathrm{Mr}$. Edwards" and his own portion) on special groups of Eocene Mollusca, which he was able to do from resources afforded by his own collection and the collections of some friends.

He maintained his activity both of mind and body up to the day of his seizure with fatal illness, which took place on the 21st, and terminated with his death on the 26th of October last. $\mathrm{He}$ was buried in the churchyard of Melton, near Woodbridge, in view of the Crag of which the study had occupied so much of his life. 